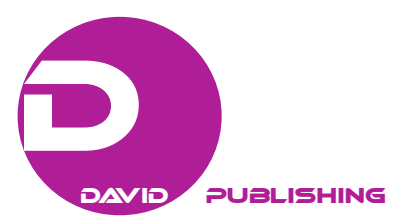

\title{
Golden Quantity Theory: Against Monetarist School
}

\author{
Gürhan Uysal \\ Ondokuz Mayis University, Samsun, Turkey
}

\begin{abstract}
This paper proposes a new perspective on quantity theory of economics. Historically, golden and silver were money, especially in Greek civilizations. Golden money standard existed during 19th century, and banknote system started in 20th century with quantity theory of Irving Fisher. Accordingly, central bank possesses banknotes in markets, which equals to total GDP (emission). This paper suggests golden quantity. In modern economy, there is IMF. It manages global monetary. Golden quantity theory is the policy that may be applied in economic crises. Accordingly, central bank prints golden, and prints banknote aligned with golden amount. That policy may increase emissions in markets, and increase total demand.
\end{abstract}

Keywords: golden quantity, IMF, central banks, emissions

\section{Introduction}

This study aims to study new phase on quantity theory of economy. There are traditional quantity theory and modern quantity theory (Uysal, 2015a). It is golden quantity theory. Traditional quantity theory is developed by Irving Fisher of Yale University (Heilbroner, 1995). It is based on national GDP. Central bank equals to emission in markets with national GDP (Uysal, 2015b). Suppose national GDP is 100 billion dollars. So, there are 100 billion dollars' emissions in markets. If emission is over than GDP, that leads to inflation in economy. Modern quantity theory is developed by Milton Friedman of Chicago University in 1970s (Heilbroner, 1995). It is based on independence of central bank. Because government forces central banks for over money supply, and that results in inflation. Monetarist policy defends independence of CB to hinder over moneysupply and inflation. This study presents a new perspective in quantity theory. Maybe, it is accepted as a modern quantity theory of economics.

\section{Literature Review: Golden Quantity Theory}

This study suggests a new quantity, especially for crises term. In economics crises GDP and emissions are decreasing; therefore, total demand in economy is lessening, and recession starts due to lack of total demand. Therefore, central bank may apply golden quantity theory to further demands. Golden quantity theory has three perspectives, centers are central bank and IMF.

(1) Central bank prints, golden. It is quantity.

(2) Central bank issues national currency according to golden quantity.

(3) IMF approval is necessary to print golden-national currency.

Gürhan Uysal, Ph.D., associate professor, School of Business, Ondokuz Mayis University, Samsun, Turkey.

Correspondence concerning this article should be addressed to Gürhan Uysal, School of Business, Ondokuz Mayis University, Kurupelit Campus, 3rd Floor, 55139, Atakum-Samsun, Turkey. 
For example, GDP was 100 billion dollars in economy, and GDP is decreasing from 100 to 50 billion dollars in economy due to crises. Therefore, money supply is smalling by time. What policy to implement? Central bank may apply golden quantity. Therefore, central bank prints 25 billion golden, and it prints 25 billion national currency, and it penetrates 25 billion national currency in markets. That policy may inflate demand in economy, and recessions stop.

Equality of quantity is important in monetarism and quantity theory. Because money supply is over, this leads to inflation in economy politics. So, if it prints 25 billion golden, and prints 25 billion national currency. This is equality in quantity.

\section{Fix Quantity Theory}

Fix quantity theory might become another alternative in money policy. Essential of money policy by CBs is to increase demand in economy. For his case, golden quantity may increase emission and demand. Total demand approach is key purpose of Keynes J. M. (Backhouse \& Bateman, 2006), Keynes aims to increase total demand in economy through IS-LM (Investment Savings-Liquidity Monetary) policy. According to IS, a central bank may issue its national currency aligned with quantity of national savings in banks. That policy would increase monetary and liquidity in markets. For example, Turkey may increase its emission by five triple of national savings. Suppose it has 1,000 TL (Turkish Lira) savings in banks; and it may print and issue 5,000 TL formarkets. Keynesian economy achieved total demand and money supply by budget deficit policy. John Hicks, economists, figured Keynesian policy as a IS-LM curve later (Backhouse \& Bateman, 2006).

This study sets fix quantity theory with national savings and foreign currency reserves. A central bank may print, issue, and penetrate national currency into business markets according to national savings of citizens in financial banks. This money policy might be proper for England economy. Because national savings are higher in economy, and Bank of England may penetrate sterlings into markets aligned with quantity of savings. For example, suppose there are 50 billion sterlings' savings in banks. BOE prints 50 billion sterling equality, and distributes this quantity into business markets in order for bumped emission and total demand.

Secondly, a central bank may print and distribute national currency aligned with foreign currency reserves in central bank accounts. This monetary policy is proper for Chinese economy. Because China is a country that has the highest foreign currency reserve in central bank. Suppose China has one billion dollars reserve in its reserve. Therefore, Chinese central bank prints juan according to dollar/juan parity (this print is aligned with quantity of dollar reserves), and it penetrates this juan into markets in order to heighten total demand.

\section{Research Methods}

In this paper, quantity theories are scanned in research. They are modern quantity theory and traditional quantity theory (Hunt, 2002). According to proposal of this study, golden quantity theory may be accepted as a modern quantity theory (Uysal, 2015c).

\section{Research Results}

IMF is center for golden quantity. A country may print and issue golden-national currency. Aim of that policy is to increase total demand in economy by emission. It is expected that golden quantity penetrates money into markets, and that increases emission level. But apply of golden quantity might be undercontrol of IMF governance. 


\section{Analysis: Silver Money}

Silver money theory is based on central bank's print of silver plates. It is similar to monetary policy and quantity theory above. So, CB prints silver money equaled to quantity of silver plate. It is ancient system in ancient's economies such as ancient Greek civilization. Because emission is smalling in economy in crises, and economy needs alternative money to do business. So, silver becomes alternative currency, and central bank withdraws these silvers from markets by issuing national currency equally. So, silver becomes alternative exchange currency in business markets in order to support business processes.

It is maybe also used for international business transactions. But IMF's control is needed. Because IMF is based on international monetary operations.

There might become four policies for economic crises:

(1) neomerchantalism;

(2) echell mobil theory;

(3) coin model;

(4) golden quantity theory.

Coin Model is applied in crises term. Central banks penetrate coins into market in economic crises. Because craftsmen and tradesmen need small money in crisis. So, CB prints one dollar, two dollars, five dollars, 10 dollars, 10 cents, 20 cents, and 50 cents, and it distributes this money into markets. So, traders use it to do business. For example, Turkish economy currently needs 1 TL and 2 TL print. Because emission is smalling economy, and traders need coin to do their business such as dolmush system, or smithchies. Therefore, small money support and finance businesses of those craftsmen. Fix Quantity approach appears in normal economy conditions. Golden quantity theory may be applied in crises time to support emission and demand in business markets. Finally, this paper argues new approaches of quantity theory for global economies.

\section{Conclusions}

To conclude, quantity is important for money supply, because if money supply is over than quantity, that policy may create inflation in economy. This is critics of monetarist school, Milton Friedman. Major quantity theory of economy is Fisher's Quantity Theory (Aren, 2014). It has acceptance worldwide by national governance. That study suggests another quantity measure for economics, it is golden. Golden is traditional investment tool; therefore, it may be accepted as a quantity variable. CBs may apply golden quantity policy in economic turmoils for increasing demand and lessening recessions.

\section{References}

Aren, S. (2014). Economic lectures. Ankara: İmge Publishing.

Backhouse, R. E., \& Bateman, B. W. (2006). Keynes. Ankara: Dost Publishing.

Heilbroner, R. L. (1995). Thought leaders of economic history. Ankara: Dost Publishing.

Hunt, E. K. (2002). History of economic thought. Ankara: Dost Publishing.

Uysal, G. (2015a). Echell mobil or gurhan uysal system on foreign currency exchange. Journal of Business and Economics, 6(9), $1630-1632$.

Uysal, G. (2015b). Golden quantity theory: Against monetarist school. 10th International Silkroad Conference, International Blacksea University, Tblisi-Georgia, May 22-24th.

Uysal, G. (2015c). From World War 1st to World War 2nd: IS-LM curve and 1929 crash. Journal of Business and Economics, $6(11), 249-252$. 